\title{
KEBIJAKAN HUTANG, KEBIJAKAN DIVIDEN, DAN PROFITABILITAS, SERTA DAMPAKNYA TERHADAP INVESTMENT OPPORTUNITY SET (IOS)
}

\author{
Andita Novianti ${ }^{\text {dan Nicodemus Simu2 }}$ \\ PERBANAS Institute Jakarta \\ E-mail : nicosimu@perbanas.id
}

\begin{abstract}
This research aimed to analyze the impact of the debt policy, dividend policy, and the profitability of each proxied by DER, DPR and ROE thru the investment opportunity set with CAPBVA as the proxy. The population of this research is a trade service company, services and investments which are listed on the Stock Exchange. The sampling method used is purposive sampling, 19 companies are selected as research objects with 76 samples of data involved. Data analysis technique is used multiple linear regression analysis. The analytical tool used to process data is E-Views 8.0. The results of this research showed that the DER and DPR has a significant negative effect on IOS, while ROE has no significant effect on IOS. The influence proportion of the independent variables can explain IOS by 16.38 percent, while 83.62 percent is explained by other variables outside the research model.
\end{abstract}

Keywords: debt policy, dividend policy, profitability, investment opportunity set

\section{PENDAHULUAN}

Keputusan investasi merupakan keputusan manajerial yang menjadi faktor utama dalam kegiatan operasional perusahaan (Sriyunianti, 2013). Investor menilai perusahaan sebagai entitas yang memiliki pertumbuhan dan prospek yang menguntungkan melalui investasi yang ditanamkannya (Panggabean dan Suratno, 2014). Pertumbuhan perusahaan yang tinggi akan memberikan adanya suatu peluang investasi yang memungkinkan adanya ruangan untuk bertumbuh. Perusahaan dengan prospek bertumbuh dapat membuat investor tertarik untuk melakukan investasi karena investor dapat mengharapkan return yang tinggi dari perusahaan tersebut (Saputro dan Lela, 2007).

Pertumbuhan bagi suatu perusahaan merupakan kesempatan investasi yang dapat menghasilkan keuntungan (Saputro dan Lela, 2007). Investment opportunity set (IOS) merupakan suatu konsep yang digunakan untuk menilai suatu perusahaan dengan mengkombinasikan aset yang dimiliki dan opsi investasi di masa depan (Myers, 1977). Investment opportunity set merupakan nilai sekarang dari pilihan-pilihan perusahaan untuk membuat keputusan investasi di masa depan (Kallapur dan Trombley, 2001 dalam Panggabean dan Suratno, 2014) atau suatu peluang yang digunakan untuk memanfaatkan sumber daya perusahaan dalam melakukan ekspansi (Panggabean dan Suratno, 2014).

Struktur modal adalah perimbangan antara ekuitas dan hutang. Keputusan struktur modal adalah pusat dari keputusan-keputusan dalam lingkup finansial dalam pemenuhan kebutuhan dana yang merupakan keputusan yang paling penting yang dibuat manajemen keuangan (Udayani dan Suaryana, 2013). Nilai investment opportunity set suatu perusahaan dapat mempengaruhi kebijakan keuangan perusahaan (Saputro dan Lela, 2007), terutama dikaitkan sumber dana untuk investasi. Sumber dana dimaksud adalah sumber dana internal dari laba ditahan atau sumber dana eksternal dari hutang (Puspitasari, 2012). Haruman (2008) dalam Wijaya (2011) berpendapat bahwa implementasi keputusan investasi sangat

\footnotetext{
${ }^{1}$ Alumni Perbanas Institute Jakarta

${ }^{2}$ Dosen FEB, Perbanas Institute Jakarta
} 
dipengaruhi oleh ketersediaan dana dalam perusahaan yang berasal dari sumber pendanaan internal (internal financing) dan sumber pendanaan eksternal (external financing). Sriyunianti (2013) menyatakan bahwa jika hutang merupakan sumber dana untuk investasi, maka penggunaan hutang tersebut akan mendorong perusahaan untuk membuat keputusan investasi. Namun demikian, harus disadari pula implikasi kebijakan keuangannya bahwa aliran kas (cash flow) yang dihasilkan dari proyek dengan net present value positif akan digunakan perusahaan sebagai jaminan hutangnya (Saputro dan Lela, 2007).

Kebijakan dividen merupakan suatu keputusan alokasi laba bersih yang akan dibagikan kepada pemegang saham (Saputro dan Lela, 2007). Sebagian laba bersih perusahaan dibagikan dalam bentuk dividen dan sebagiannya lagi ditahan untuk diinvestasikan kembali ke perusahaan (Yendrawati dan Febi, 2013). Semakin tinggi laba yang dialokasikan untuk pembayaran dividen berdampak langsung terhadap semakin rendahnya dana yang dapat diinvestasikan kembali ke dalam perusahaan. Keputusan mengenai pembayaran dividen dapat menimbulkan persoalan bagi perusahaan karena adanya perbedaan kepentingan antara manajer dan pemegang saham. Manajer menginginkan sebagaian besar laba diinvestasikan kembali untuk mendapatkan laba perusahaan yang lebih besar, sedangkan pemegang saham lebih menyukai laba yang diperoleh perusahaan dibagikan sebagai dividen (Jensen, 1986 dalam Puspitasari, 2012). Dengan demikian, keputusan ini akan berdampak pada ketersediaan dana perusahaan yang akan digunakan untuk melakukan investasi.

Profitabilitas merupakan ukuran kemampuan perusahaan dalam menghasilkan laba atau keuntungan. Semakin tinggi laba yang dihasilkan perusahaan, semakin tinggi pula ketersediaan kas untuk mendanai investasi perusahaan (Subchan dan Sudarman, 2011). Penelitian lain menyebutkan pula bahwa, profitabilitas perusahaan merupakan sinyal pertumbuhan dimasa mendatang (Lestari, 2004). Jika kedua pernyataan di atas dikaitkan, maka kesimpulannya adalah semakin tinggi profitabilitas yang dapat diperoleh, semakin besar dana yang dapat diinvestasikan ke perusahaan, dan semakin tinggi pula pertumbuhan perusahaan.

Profitabilitas perusahaan yang tinggi memberikan sinyal yang positif bagi investor dan kreditor sehingga membuat perusahaan dapat lebih mudah mendapatkan sumber dana eksternal. Profitabilitas menjadi dasar pertimbangan bagi investor dan kreditor dalam mengambil suatu keputusan untuk menginvestasikan dananya ke dalam perusahaan (Saputro dan Lela, 2007). Investor dan kreditor akan melihat kinerja perusahaan dalam memanfaatkan sumber daya perusahaannya untuk menghasilkan laba. Semakin tinggi keuntungan yang dihasilkan perusahaan maka, semakin besar perusahaan akan memperoleh kepercayaan dari calon investor dan kreditor (Hidayat, 2010).

\section{KERANGKA TEORITIS DAN PENGEMBANGAN HIPOTESIS}

\section{Agency Theory}

Teori keagenan merupakan suatu teori yang menjelaskan hubungan keagenan antara principle dan agent serta masalah-masalah yang terjadi dalam keagenan suatu perusahaan (Sriyunianti, 2013). Hubungan keagenan adalah hubungan di antara pihak pengelola perusahaan yang disebut sebagai agent dengan pemilik perusahaan yang disebut sebagai principle (Husnan dan Enny, 2015). Masalah keagenan sering terjadi pada setiap perusahaan karena adanya perbedaan kepentingan antara manajer dengan pemegang saham (Puspitasari, 2012) dan mempengaruhi perilaku kedua belah pihak ini untuk memaksimalkan kesejahteraan masing-masing (Lestari, 2004).

Manajer idealnya membuat keputusan yang bertujuan untuk memaksimalkan kesejahteraan pemegang saham (Husnan dan Enny, 2015), meskipun bisa saja terjadi bahwa keputusan tersebut memang dilatarbelakangi oleh motivasi untuk memaksimalkan 
kesejahteraan pemegang saham atau bahkan hanya untuk mencapai tujuan yang berbeda. Lestari (2004) menyatakan bahwa perbedaan kepentingan antara manajemen dan pemilik inilah yang menyebabkan kekurangpercayaan pemegang saham terhadap keputusan yang diambil oleh manajer. Oleh karena itu, pemegang saham cenderung melakukan pengawasan yang ketat terhadap kinerja manajer dalam perusahaan agar masalah keagenan ini dapat diminimalisasikan. Ketika pemegang saham melakukan pengawasan terhadap manajemen, maka pengawasan tersebut akan menimbulkan apa yang disebut monitoring cost (Lestari, 2004).

\section{Investment Opportunity Set}

Investment opportunity set (IOS) merupakan suatu konsep yang digunakan untuk menilai suatu perusahaan dengan mengkombinasikan aset yang dimiliki dan pilihan investasi di masa depan (Myers, 1977). Investment opportunity set merupakan nilai sekarang dari berbagai pilihan yang dimiliki perusahaan untuk keputusan investasi di masa depan (Kallapur dan Trombley, 2001 dalam Panggabean dan Suratno, 2014). Subchan dan Sudarman (2011) mengatakan bahwa pertumbuhan merupakan kemampuan perusahaan dalam meningkatkan ukuran perusahaan sedangkan investment opportunity set merupakan opsi untuk berinvestasi dalam proyek yang memiliki net present value positif.

Menurut Halim (2005), net present value positif menunjukkan bahwa dana yang diinvestasikan dalam proyek tertentu menghasilkan present value cash flow lebih besar daripada present value original investment. Sebaliknya, net present value negatif menggambarkan bahwa dana yang diinvestasikan di dalam suatu proyek menghasilkan present value cash flow lebih kecil jika dibandingkan dengan present value original investment. Dengan demikian, proyek yang dapat diterima adalah proyek dengan nilai NPV lebih besar atau sama dengan nol, sementara proyek dengan nilai NPV lebih kecil daripada nol dapat ditolak oleh manajemen (Sudana, 2011).

Investment opportunity set merupakan suatu variabel laten yang sifatnya tidak dapat diobservasi. Oleh karena itu, diperlukan suatu proksi untuk mengukurnya. Mengingat tidak terdapatnya kesepakatan di antara para ahli keuangan untuk mengukur besaran IOS, maka terdapat beberapa alternatif sebagai dasar pengukurannya. Beberapa alternatif sebagai dasar untuk melakukan proksi pada IOS, antara lain (Evana, 2009), proksi berdasarkan harga (price-based proxies), proksi berdasarkan varian (variance-based proxies), dan proksi berdasarkan investasi (investment-based proxies). Proksi berdasarkan harga pasar berarti bahwa prospek pertumbuhan perusahaan tergambar pada harga pasar saham. Perusahaan yang tumbuh pada umumnya memiliki nilai pasar lebih tinggi dibandingkan nilai bukunya. Proksi berdasarkan varian berlandaskan pada asumsi bahwa IOS sebagai suatu ukuran pertumbuhan perusahaan akan lebih bernilai jika menggunakan dasar variabilitas sebagai dasar pengukurannya. Variabilitas ini dapat bersumber pada variabilitas tingkat pengembalian (return) yang mendasari adanya perubahan aktiva atau bahkan terjadinya variabilitas pada aktiva jika dibandingkan dengan nilai penjualan yang diperoleh berdasarkan aktiva tersebut (asset deflated sales). Proksi berdasarkan investasi menyatakan bahwa perusahaan yang memiliki aktiva yang tinggi pada dasarnya memiliki peluang tumbuh yang tinggi atau dengan kata lain, perusahaan yang memiliki IOS tinggi adalah perusahaan yang biasanya memiliki tingkat investasi tinggi, yang ditunjukkan dengan tingginya aktiva yang dimilikinya.

Kallapur dan Trombley (2001) dalam Puspitasari (2012) menyebutkan pula bahwa proksi investment opportunity set berbasis investasi terbentuk dari suatu rasio yang membandingkan suatu pengukuran investasi. Investasi tersebut dalam bentuk aktiva tetap atau suatu hasil operasi yang diproduksi dari aktiva yang telah diinvestasikan perusahaan. Rasio yang biasanya digunakan untuk menghitung IOS berdasarkan proksi investasi adalah capital expenditure to market value of asset ratio (CAPMVA) atau capital expenditure to book value of asset ratio (CAPBVA). Capital expenditure to market value of asset ratio mengacu pada sutatu konsep bahwa perusahaan yang tumbuh pada dasarnya pasti 
memiliki level aktivitas investasi yang lebih tinggi dibanding dengan perusahaan yang tidak tumbuh, sementara capital expenditure to book value of asset ratio merujuk pada dana yang tersedia yang digunakan untuk memperoleh aset fisik atau aset produktif.

\section{Keterkaitan antara Kebijakan Hutang dan IOS}

Kebijakan hutang digunakan sebagai alat untuk mengukur tingkat hutang yang digunakan perusahaan dalam membiayai aktiva perusahaan (Yendrawati dan Febi, 2013). Penggunan hutang akan menunjukkan tingkat ketergantungan perusahaan kepada kreditor. Hutang yang tinggi pada suatu perusahaan juga menggambarkan potensi tingkat pertumbuhan yang rendah di perusahaan tersebut (Puspitasari, 2012). Myers (1977) menyatakan bahwa "perusahaan tidak meminjam uang sebanyak mungkin karena untuk mengurangi kerugian yang akan timbul dari hutang itu sendiri. Biaya yang timbul dari hutang tersebut adalah biaya kepailitan ketika perusahaan tidak dapat memenuhi kewajibannya".

Apabila hutang digunakan sebagai salah satu sumber dana untuk investasi maka keberadaan hutang tersebut akan mendorong manajer untuk mengambil keputusan investasi sedangkan apabila hutang tersebut digunakan sebagai mekanisme pengendalian maka hutang tersebut memiliki pengaruh yang negatif terhadap keputusan investasi (Sriyunianti, 2013). Dalam hal ini, manajer tidak akan membuat keputusan dengan menggunakan hutang yang tinggi karena dapat menurunkan nilai perusahaan.

Semakin tinggi hutang yang digunakan oleh perusahaan maka semakin besar biaya bunga yang akan ditanggung oleh perusahaan. Suatu perusahaan yang tidak dapat membayar kewajiban serta biaya bunganya maka akan berdampak terhadap rendahnya tingkat investasi di masa depan (Saputro dan Lela, 2007). Dalam hal ini, manajer tidak akan membuat keputusan dengan menggunakan hutang yang tinggi karena dapat menurunkan nilai perusahaan. Berdasarkan uraian tersebut, kiranya hipotesis yang muncul adalah sebagai berikut:

H1: Kebijakan hutang berpengaruh terhadap negatif investment opportunity set.

\section{Keterkaitan antara Kebijakan Dividen dan IOS}

Kebijakan dividen merupakan suatu keputusan manajer mengenai seberapa besar laba bersih perusahaan akan dibagikan kepada pemegang saham (Saputro dan Lela, 2007). Sebagian laba bersih perusahaan dibagikan dalam bentuk dividen dan sebagiannya lagi ditahan untuk diinvestasikan kembali ke perusahaan (Yendrawati dan Febi, 2013). Apabila pembayaran dividen dilakukan dalam jumlah yang besar maka akan membuat kecilnya dana yang tersedia untuk diinvestasikan kembali ke perusahaan. Hal inilah yang melandasi timbulnya perilaku pecking order yang berdampak pada penggunaan laba ditahan (Saputro dan Lela, 2007).

Yendrawati dan Febi (2013) menyatakan bahwa perusahaan yang bertumbuh melakukan pembayaran dividen dalam jumlah yang rendah mengingat sebagian besar laba tersebut digunakan untuk membiayai ekspansi perusahaan. Jensen (1986) dalam Lestari (2004) juga menyatakan bahwa perusahaan yang mempunyai tingkat pertumbuhan yang rendah akan membagikan dividen dalam jumlah yang besar. Dengan demikian, besar kecilnya pembayaran dividen dapat dilakukan dengan melihat pertumbuhan perusahaan. Semakin tinggi dividen yang dibayarkan, maka dana yang tersedia untuk diinvestasikan kembali akan semakin rendah. Hal ini dikarenakan laba yang diperoleh perusahaan dialokasikan untuk membayar dividen kepada pemegang saham sehingga berkurangnya laba ditahan untuk kebutuhan investasi (Saputro dan Lela, 2007). Berdasarkan uraian di atas maka dapat dirumuskan hipotesis sebagai berikut:

\section{H2: Kebijakan Dividen berpengaruh negatif terhadap investment opportunity set}

\section{Keterkaitan antara Profitabilitas dengan IOS}


Profitabilitas merupakan kemampuan perusahaan dalam menghasilkan laba dengan memanfaatkan aktiva atau ekuitas yang dimiliki perusahaan. Semakin tinggi laba yang dihasilkan perusahaan, maka semakin tinggi juga kas yang tersedia untuk mendanai investasi perusahaan (Subchan dan Sudarman, 2011). Selain itu, profitabilitas juga merupakan sinyal pertumbuhan dimasa mendatang (Lestari, 2004). Profitabilitas perusahaan yang tinggi memberikan sinyal yang positif bagi investor dan kreditor sehingga membuat perusahaan dapat lebih mudah mendapatkan sumber dana eksternal. Semakin tinggi profitabilitas perusahaan, maka semakin tinggi pula pertumbuhan perusahaan sehingga semakin besar dana yang dapat diinvestasikan ke perusahaan Saputro dan Lela (2007).

Profitabilitas menjadi dasar pertimbangan bagi investor dan kreditor dalam mengambil suatu keputusan untuk menginvestasikan dananya ke dalam perusahaan (Saputro dan Lela, 2007). Investor dan kreditor akan melihat kinerja perusahaan dalam memanfaatkan sumber daya perusahaannya untuk menghasilkan laba. Profitabilitas menggambarkan seberapa besar pertumbuhan perusahaan pada periode tertentu. Profitabilitas yang tinggi mengindikasikan bahwa perusahaan memiliki potensi tingkat bertumbuh yang lebih besar di masa mendatang (Puspitasari, 2012). Pertumbuhan perusahaan akan memberikan sinyal yang positif bagi investor dan kreditor untuk menanamkan dananya. Semakin besar dana yang dimiliki perusahaan, maka semakin besar manajer dapat mengambil keputusan untuk menginvestasikan sumber dana tersebut ke dalam investasi yang menguntungkan agar dapat meningkatkan nilai perusahaan. Berdasarkan uraian di atas, maka hipotesis yang diajukan adalah sebagai berikut:

\section{H3: Profitabilitas berpengaruh positif terhadap investment opportunity set.}

\section{METODE PENELITIAN}

Penelitian ini adalah penelitian kausalitas dengan menggunakan data sekunder yang bersumber dari laporan keuangan yang listing di BEl periode 2010 sampai dengan 2014 untuk perusahaan jasa sektor perdagangan, jasa dan investasi.

Data dalam penelitian ini diambil dengan metode purposive sampling, dengan kriteria sebagai berikut.

1) Perusahaan tidak pernah delisting dan relisting selama periode 2011 sampai dengan 2014;

2) Perusahaan telah menerbitkan dan mempublikasikan laporan keuangan yang telah di audit untuk tahun buku 2011 sampai dengan tahun 2014;

3) Perusahaan tidak pernah memperoleh laba negatif selama periode 2011 sampai dengan 2014;

4) Perusahaan selalu membayar dividen secara teratur selama periode 2011 sampai dengan 2014; dan

5) Perusahaan mengalami penurunan aset tetap maksimal satu kali selama periode 2011 sampai dengan 2014.

Berdasarkan kelima kriteria di atas, diperoleh 19 perusahaan yang akan dijadikan objek penelitian. Dengan demikian, jumlah total data sampel untuk seluruh periode pengamatan adalah sebanyak 76 data sampel. Perusahaan yang dijadikan objek penelitian adalah PT AKR Corporindo, Tbk. (AKRA), PT Lautan Luas, Tbk. (LTLS), PT Moden Internasional, Tbk. (MDRN), PT Tunas Ridean, Tbk. (TURI), PT Ace Hardware Indonesia, Tbk. (ACES), PT Mitra Adiperkasa, Tbk. (MAPI), PT Midi Utama Indonesia, Tbk. (MIDI), PT Matahari Putra Prima, Tbk. (MPPA), PT Fast Food Indonesia, Tbk. (FAST), PT Panorama Sentrawisata, Tbk. (PANR), PT Pembangunan Jaya Ancol, Tbk. (PJAA), PT Pudjiadi and Sons, Tbk. (PNSE), PT Elang Mahkota Teknologi, Tbk. (EMTK), PT Jasuindo Tiga Perkasa, Tbk. (JTPE), dan PT Media Nusantara Citra, Tbk. (MNCN).

Variabel yang digunakan di dalam penelitian ini terdiri dari tiga variabel independen, yaitu kebijakan hutang, kebijakan dividen, dan profitabilitas dan satu variabel dependen, yaitu investment opportunity set. Data yang digunakan dalam penelitian ini adalah data panel, yang memiliki karakteristik cross section dan time series secara bersamaan. Pengolahan data 
dilakukan dengan bantuan microsoft Excel 2010 dan E-Views 8.0. Penjelasan masing-masing variabel adalah sebagai berikut.

\section{Kebijakan Hutang}

Penelitian ini menggunakan debt to equity ratio (DER $=X_{1}$ ) sebagai proksi dari kebijakan hutang. Debt to equity ratio merupakan rasio yang digunakan untuk mencari perbandingan antara penggunaan hutang yang diperoleh dari pihak luar dengan modal sendiri. Debt to equity ratio mewakili pengukuran dari kebijakan hutang perusahaan. Berdasarkan rasio ini dapat diketahui porsi ketrergantungan perusahaan terhadap sumber dana eksternal dibandingkan dengan sumber dana internal. Pengukuran variabel debt to equity ratio dapat dihitung dengan rumus berikut ini:

$$
\mathrm{DER}=\frac{\text { total liabilities }}{\text { total equity }}
$$

\section{Kebijakan Dividen}

Dividend payout ratio (DPR $=\mathrm{X}_{2}$ ) merupakan persentase pembagian laba perusahaan kepada pemegang saham dalam bentuk dividen tunai per lembar saham. Dividend payout ratio mewakili pengukuran dari kebijakan dividen. Semakin tinggi dividen payout ratio menunjukan semakin rendah dana yang diinvestasikan kembali ke dalam perusahaan. Pengukuran variabel dividend payout ratio dapat dihitung dengan rumus berikut ini:

\section{Profitabilitas}

$$
\mathrm{DPR}=\frac{\text { dividend per share }}{\text { earning per share }}
$$

Return on equity ratio $\left(\mathrm{ROE}=\mathrm{X}_{3}\right)$ adalah pengukuran tingkat pengembalian yang akan diterima oleh investor pemegang saham. Penggunaan Return on equity ratio dianggap mewakili pengukuran untuk profitabilitas. Semakin tinggi ROE, menunjukkan semakin besar pula potensi pertumbuhan perusahaan. Pengukuran variabel return on equity ratio dapat dihitung dengan rumus berikut ini:

4. Investment Opportunity Set $(Y)$

$$
\mathrm{ROE}=\frac{\text { earning after tax }}{\text { total equity }}
$$

Investment opportunity set merupakan suatu konsep yang digunakan untuk menilai suatu perusahaan dengan mengkombinasikan aset yang dimiliki dan opsi investasi di masa depan (Myers, 1977). Capital expenditure to book value of asset ratio (CAPBVA) merupakan rasio pengukuran investment opportunity set berbasis investasi yang secara umum menunjukkan adanya aliran tambahan modal saham perusahaan yang dapat digunakan untuk tambahan investasi aktiva produktifnya. Pengukuran variabel capital expenditure to book value of asset ratio dapat dihitung dengan rumus berikut ini:

$$
\text { CAPBVA }=\frac{\text { fixed asset }_{t}-\text { fixed }_{\text {asset }} t-1}{\text { total assets }_{t}}
$$

\section{HASIL DAN PEMBAHASAN}

Penelitian ini dilakukan untuk menguji pengaruh variabel independen, yaitu debt to equity ratio, dividend payout ratio dan return on equity ratio terhadap variabel dependen, yaitu investment opportunity set. Analisis data dilakukan dengan menggunakan regresi data panel pada 19 perusahaan yang menjadi objek penelitian dan melibatkan 76 sampel data panel. Statistik deskriptif dari variabel yang diabalisis ditunjukkan pada tabel berikut.

Tabel 1. Statistik Deskriptif

\begin{tabular}{|l|r|r|r|r|}
\hline \multicolumn{1}{|c|}{ KETERANGAN } & \multicolumn{1}{c|}{ IOS } & \multicolumn{1}{c|}{ DER } & \multicolumn{1}{c|}{ DPR } & \multicolumn{1}{c|}{ ROE } \\
\hline Mean & 0.0467 & 1.1437 & 0.4011 & 0.1658 \\
\hline Median & 0.0400 & 0.8800 & 0.3000 & 0.1450 \\
\hline Maximum & 0.2800 & 3.2400 & 4.7000 & 0.6400 \\
\hline Minimum & -0.1100 & 0.0800 & 0.0600 & 0.0100 \\
\hline Std. Dev. & 0.0577 & 0.8074 & 0.5791 & 0.0989 \\
\hline
\end{tabular}

Sumber: Data diolah. 
Berdasarkan tabel di atas, terlihat bahwa variabel investment opportunity set memiliki nilai rata-rata sebesar 0.0467 dengan nilai tertinggi 0.2800 dan nilai terendah -0.1100 , serta standar deviasi 0.0577 . Nilai investment opportunity set yang tertinggi dimiliki oleh Multifiling Mitra Indonesia, Tbk pada tahun 2012 dan nilai investment opportunity set yang terendah dimiliki oleh Matahari Putra Prima, Tbk pada tahun 2011.

Pada variabel kedua, yaitu debt to equity ratio, nilai rata-rata adalah sebesar 1.1437 dengan nilai tertinggi 3.2400 dan nilai terendah 0.0800 , serta standar deviasi 0.8074 . Nilai debt to equity ratio yang tertinggi dimiliki oleh Lautan Luas, Tbk pada tahun 2011 dan nilai debt to equity ratio yang terendah dimiliki oleh Multifiling Mitra Indonesia, Tbk pada tahun 2014.

Pada variabel dividend payout ratio memiliki nilai rata-rata sebesar 0.4011 dengan nilai tertinggi 4.7000 dan nilai terendah 0.0600 , serta standar deviasi 0.5791 . Nilai dividend payout ratio yang tertinggi dimiliki oleh Matahari Putra Prima, Tbk pada tahun 2012 dan nilai dividend payout ratio yang terendah dimiliki oleh Metrodata Electronics, Tbk pada tahun 2014.

Pada variabel return on equity ratio memiliki nilai rata-rata sebesar 0.1658 dengan nilai tertinggi 0.6400 dan nilai terendah 0.0100 , serta standar deviasi 0.0989 . Nilai return on equity ratio yang tertinggi dimiliki oleh AKR Korporindo, Tbk pada tahun 2011 dan nilai return on equity ratio yang terendah dimiliki oleh Multipolar, Tbk pada tahun 2011.

Selanjutnya analisis data dilakukan dengan analisis regresi linier berganda. Pemilihan model regresi dengan menggunakan program statistik E-Views 8.0 dan dengan mengikuti tahapan uji Chow dan Uji Lagrange Multiplier diperoleh hasil bahwa metode common effect (ordinary least square $=\mathrm{OLS}$ ) adalah model terbaik, dibandingkan dengan metode fixed effect model (FEM) atau pun random effect model (REM)

Metode OLS sebagai dasar pendekatan mengharuskan dilakukannya beberapa uji model regresi. Khusus untuk regresi data panel, pengujian asumsi klasik model regresi hanya dilakukan untuk multikolinearitas dan heteroskedastisitas (Iabal, 2015). Hasil perhitungan dengan menggunakan program EViews 8.0 mengindikasikan tidak terjadinya gejala multikolinearitas dan heteroskedastisitas sehingga model persamaan regresi yang diperoleh bersifat tidak bias, konsisten, dan memiliki ketepatan untuk melakukan estimasi. Tabel pada bagian berikut ini menunjukkan hasil estimasi model regresi data panel. 


\section{Tabel 2. Hasil Estimasi Regresi Model Common Effect}

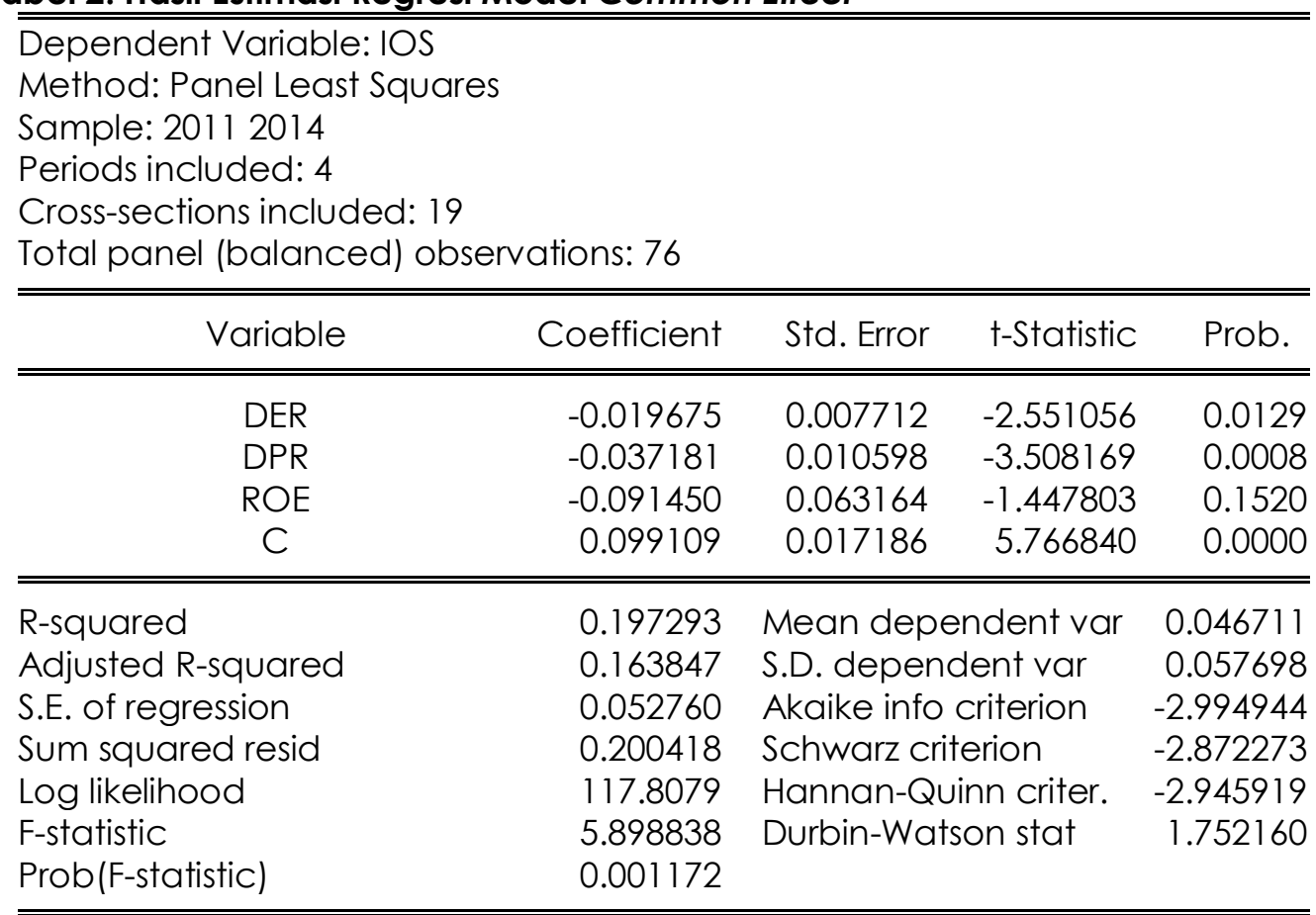

Sumber: Data diolah.

Berdasarkan tabel tersebut terlihat bahwa model persamaan regresi linear berganda yang diperoleh adalah:

$$
\text { IOS = 0,0991-0,0197 DER - 0,0372 DPR - 0,0915 ROE + e }
$$

Persamaan regresi tersebut berarti bahwa pergerakan IOS berbanding terbalik dengan pergerakan variabel-variabel prediktornya. Dengan kata lain, jika besarnya hutang, porsi dana untuk dibagikan sebagai dividen, dan besarnya ROE--baik secara sendiri-sendiri, maupun secara bersama--meningkat, maka peluang yang tersedia untuk melakukan investasi (IOS) semakin mengecil. Sebaliknya, peluang investasi akan lebih terbuka apabila tingkat porsi utang dan/atau porsi laba yang yang diinvestasikan kembali ke dalam perusahaan dan/atau besaran ROE yang diperoleh menurun.

Dari tabel tersebut juga dapat diketahui bahwa masing-masing variabel memiliki kontribusi yang berbeda-beda terhadap besaran estimasi IOS. Besarnya sumbangan masing-masing variabel tersebut ditunjukkan pada koefisien $\beta$ pada persamaan regresi. Di dalam hal ini, variabel ROE merupakan variabel yang memberikan kontribusi tertinggi $(-0.091450)$, dilanjutkan dengan variabel DPR (-0.037181), dan yang terendah (-0.019675) adalah variabel DER.

Pengujian hipotesis dilakukan dengan membandingkan nilai prob. pada masing-masing variabel dengan nilai a $(0,05)$. Kriteria yang digunakan adalah jika nilai Prob. lebih rendah daripada a $(0,05)$, maka terdapat pengaruh signifikan variabel independen tersebut terhadap variabel dependen. Berdasarkan tabel di atas, terlihat bahwa besaran nilai prob untuk variabel DER dan DPR masing-masing sebesar 0.0129 dan 0.0008 dan angka ini berada di bawah a $(0,05)$. Dengan demikian terdapat pengaruh signifikan masing-masing variabel DER dan DPR terhadap IOS dan dengan memperhatikan koefisien $\beta$, makanya pengaruhnya tersebut bersifat negatif. Selanjutnya nilai prob untuk variabel ROE adalah sebesar 0,1520 dan berada di atas a $(0,05)$ sehingga dapat disimpulkan bahwa pengaruh ROE terhadap IOS bersifat tidak signifikan.

Selanjutnya dilakukan uji goodness of fit yang berfungsi untuk menilai kelayakan atau "goodness of fit" dari model yang dikembangkan atau apakah variabel-variabel yang digunakan untuk mengembangkan model mampu digunakan untuk menjelaskan 
fenomena yang dianalisis. Dalam kaitannya dengan persamaan regresi sebagai hasil dari analisis regresi berganda, uji goodness of fit diarahkan untuk melihat apakah hasil prediksi dari model yang dikembangkan tersebut secara statistik dapat dipercaya dan dipertanggungjawabkan. Alat untuk goodness of fit ini adalah prob(F-statistic) dengan kriteria pengujian adalah apabila nilai prob(F-statistic) lebih rendah daripada a $(0,05)$, maka hipotesis diterima dan model memiliki tingkat kelayakan yang tinggi dan dapat disimpulkan bahwa semua variabel independen secara bersama-sama dapat menjelaskan variabel dependen yang dianalisis. Berdasarkan tabel di atas terlihat bahwa nilai prob(F-statistic) adalah sebesar $0.001172<$ a $(0,05)$. Dengan demikian, variabel prediktor, yaitu DER, DPR, dan ROE secara bersama-sama mampu menjelaskan fenomena pergerakan IOS. Koefisien adjusted R-squared yang diperoleh adalah sebesar 0.163847 menunjukkan bahwa kontribusi pengaruh variabel debt to equity ratio, dividend payout ratio dan return on equity ratio secara bersama-sama terhadap variabel investment opportunity set adalah sebesar 16.38 persen, dan selebihnya, yaitu 83.62 persen dipengaruhi oleh faktor lain di luar dari variabel prediktor yang digunakan di dalam penelitian ini.

Hasil pengujian pada variabel debt to equity ratio (DER) terhadap investment opportunity set (IOS) membuktikan bahwa DER berpengaruh negatif signifikan terhadap IOS. Pada umumnya, semakin tinggi hutang yang digunakan oleh perusahaan secara langsung akan berdampak pada semakin tingginya beban beban biaya tetap yang menjadi tanggungan perusahaan, yaitu beban biaya absolut atas penggunaan dana. Selain itu, porsi hutang yang semakin meningkat di dalam struktur modal--baik absolut maupun relatif-- secara tidak langsung akan berdampak pada potensi risiko yang dihadapi perusahaan dan kemudian diimplementasikan menjadi besaran tingkat bunga yang semakin tinggi. Perusahaan yang tidak dapat membayar kewajiban hutangnya beserta beban bunganya akan berdampak terhadap rendahnya tingkat investasi di masa depan (Saputro dan Lela, 2007). Mengingat penggunaan hutang yang terlalu tinggi dapat menyebabkan krisis keuangan bagi perusahaan (Myers, 1977) dan mengurangi keleluasaan perusahaan untuk menggunakan dananya untuk ekspansi, perusahaan disarankan tidak menggunakan hutang yang terlalu tinggi dalam struktur modalnya. Hasil penelitian ini mendukung penelitian yang dilakukan oleh (Saputro dan Lela, 2007), (Sriyunianti, 2013), (Subchan dan Sudarman, 2011), (Lestari, 2004), dan (Sari, 2015) yang menyimpulkan bahwa DER berpengaruh negatif signifikan terhadap IOS. Namun demikian, penelitian ini juga memiliki hasil yang berbeda dibandingkan dengan penelitian yang dilakukan oleh Yendrawati dan Febi (2013) menyatakan bahwa DER tidak berpengaruh signifikan terhadap IOS atau pun penelitian Panggabean dan Suratno (2014) menyatakan bahwa DER berpengaruh positif signifikan terhadap IOS.

Hasil pengujian pada variabel dividend payout ratio (DPR) dan pengaruhnya terhadap investment opportunity set (IOS) membuktikan bahwa DPR berpengaruh negatif signifikan terhadap IOS. Hal ini sejalan dengan teori yang menyatakan bahwa semakin tinggi porsi dana yang dialokasi untuk pembagian dividen, semakin rendah pula dana yang tersedia untuk diinvestasikan kembali ke dalam perusahaan. Hal ini disebabkan oleh berkurangnya porsi laba ditahan untuk kebutuhan investasi (Saputro dan Lela, 2007). Perusahaan yang mempunyai tingkat pertumbuhan yang tinggi hendaknya mengurangi pembayaran dividen kepada pemegang saham, dan kemudian sebaiknya mengalokasi laba yang diperoleh kepdaa investasi menguntungkan sehingga dapat meningkatkan nilai tambah perusahaan. Penelitian ini mendukung hasil penelitian yang dilakukan oleh (Yendrawati dan Febi, 2013) dan (Subchan dan Sudarman, 2011) bahwa DPR berpengaruh negatif signifikan terhadap IOS. Di sisi lain, penelitian ini berbeda dengan kesimpulan penelitian yang dilakukan Saputro dan Lela (2007), Puspitasari (2012), dan Lestari (2004), yaitu DPR tidak berpengaruh signifikan terhadap investment opportunity set.

Hasil pengujian pengaruh variabel return on equity ratio (ROE) terhadap investment opportunity set membuktikan bahwa ROE tidak berpengaruh signifikan terhadap IOS. Sebagaimana diketahui, ROE merupakan kemampuan perusahaan dalam menghasilkan laba berdasarkan ekuitas yang dimiliki perusahaan. Laba yang dihasilkan perusahaan 
digunakan untuk memberikan tingkat pengembalian (return) sebesar-besarnya untuk meningkatkan kesejahteraan pemegang saham. Bentuk peningkatan kesejahteraan ini diterjemahkan antara lain melalui pembagian dividen sebagai bagian dari pembagian keuntungan yang dinikmati pemegang saham dan peningkatan market value dari saham perusahaan sehingga pemegang saham dapat memperoleh capital gain. Dengan demikian laba yang dihasilkan perusahaan tidak ada kaitannya dengan sejumlah dana yang diinvestasikan pada bentuk investasi real asset atau pun menambah aset yang dimiliki perusahaan. Hal ini juga berarti bahwa tinggi rendahnya profitabilitas yang diproksikan dengan ROE juga tidak berkaitan dengan IOS perusahaan. Penelitian ini mendukung hasil penelitian yang dilakukan oleh Panggabean dan Suratno (2014), yaitu ROE tidak berpengaruh terhadap investment opportunity set. Hasil temuan penelitian ini berbeda dengan hasil temuan Saputro dan Lela (2007) yang menyatakan bahwa profitabilitas berpengaruh positif terhadap investment opportunity set.

\section{KESIMPULAN}

Berdasarkan hasil analisis dan pembahasan yang telah diinterpretasikan pada bab sebelumnya, maka dapat ditarik kesimpulan terkait pengaruh variabel kebijakan hutang (DER), kebijakan dividen (DPR) dan profitabilitas (ROE), sebagai berikut.

1. Kebijakan hutang yang diproksikan melalui debt to equity ratio (DER) berpengaruh negatif signifikan terhadap investment opportunity set (IOS).

2. Kebijakan dividen yang diproksikan melalui dividend payout ratio (DPR) berpengaruh negatif signifikan terhadap investment opportunity set (IOS).

3. Return on equity ratio (ROE) sebagai proksi dari profitabilitas tidak berpengaruh signifikan terhadap investment opportunity set (IOS).

\section{IMPLIKASI}

Pengaruh negatif DER terhadap IOS menunjukkan bahwa semakin tinggi hutang berdampak secara langsung atas beban pembayaran prinsipal dan beban bunga, selanjutnya mempengaruhi ketersediaan dana untuk mengantisipasi peluang investasi di masa depan, dan pada gilirannya juga dapat memperlambat tingkat pertumbuhan perusahaan. Oleh karena itu, pada saat pengambilan keputusan pendanaan, terutama yang bersumber dari sumber dana pinjaman, manajemen perusahaan hendaknya tidak hanya berpedoman pada keharusan di dalam ketersediaan dana untuk kebutuhan investasi saat ini, melainkan juga memperhatikan potensi dampak pinjaman tersebut pada beban tetap yang menjadi tanggu ngan perusahaan dan dampaknya terhadap akselerasi pertumbuhan pada masa yang akan datang.

\section{DAFTAR PUSTAKA}

Evana, Einde. 2009. Analisis Hubungan Investment Opportunity Set (IOS) Berdasarkan Nilai Pasar dan Nilai Buku dengan Realisasi Pertumbuhan. Jurnal Akuntansi dan Kevangan, XIV(2): 167-186.

Halim, Abdul. 2005. Analisis Investasi. Edisi Kedua. Jakarta: Salemba Empat.

Haruman, T. 2008. Pengaruh Struktur Kepemilikan Terhadap Keputusan Keuangan dan Nilai Perusahaan Survey pada Perusahaan Manufaktur di PT. Bursa Efek Indonesia. Simposium Nasional Akuntansi XI: Ikatan Akuntan Indonesia

Husnan, Suad dan Enny Pudjiastuti. (2015). Dasar-Dasar Manajemen Keuangan. Edisi Ketujuh. Yogyakarta: UPP STIM YKPN.

labal, Muhammad. 2015. Regresi Data Panel (2): Tahap Analisis. (https://dosen.perbanas.id/regresi-data-panel-2-tahap-analisis/), diakses 22 Juli 2016). 
Lestari, Holydia. 2004. Pengaruh Kebijakan Utang, Kebijakan Dividen, Risiko dan Profitabilitas Terhadap Set Kesempatan Investasi. Simposium Akuntansi Nasional VII, Bali.

Kallapur, Sanjay and Mark K. Trombley. 2001. The Investment Opportunity Set: Determinants, Consequences and Measurement. Managerial Finance. vol.27 no.3: p.3-15.

Myers, Stewart C. 1977. Determinants of Corporate Borrowing. Journal of Financial Economics, V: 147-175.

Panggabean, Hotman $\mathrm{P}$ dan Suratno. 2014. Faktor-Faktor Fundamental Keuangan Perusahaan dan Investment Opportunity Set Perusahaan Real Estate. Jurnal Riset Akuntansi dan Perpajakan, 1(1): 60-70.

Puspitasari, Novi. 2012. Kinerja Finansial dan Kesempatan Investasi Perusahaan Bertumbuh dan Tidak Bertumbuh. Jurnal Bisnis dan Manajemen BISMA, VI(1).

Saputro, Adi Akhmad dan Lela Hindasah. 2007. Pengaruh Kebijakan Pendanaan dan Profitabilitas Perusahaan Terhadap Set Kesempatan Investasi (IOS). Jurnal Akuntansi dan Investasi, VII(1): 58-71.

Sari, Wulan India. 2015. Faktor-Faktor yang Mempengaruhi Set Kesempatan Investasi pada Perusahaan Manufaktur yang Terdaftar di Bursa Efek Indonesia. Jurnal Penelitian Fakultas Ekonomi dan Bisnis.

Sriyunianti, Fera. 2013. Pengaruh Aliran Kas Bebas dan Kebijakan Utang terhadap Keputusan Investasi. Jurnal Akuntansi dan Manajemen, VIII(2): 77-87.

Subchan dan Sudarman. 201 1. Pengaruh Kebijakan Utang, Kebijakan Dividen, Risiko Investasi dan Profitabilitas Perusahaan Terhadap Set Kesempatan Investasi. Jurnal Dharma Ekonomi, XVIII(33).

Sudana, I Made dan Novietha I. Sallama (Ed). 2011. Manajemen Keuangan Perusahaan Teori dan Praktik. Jakarta: Erlangga.

Udayani, Dewi dan I Gusti Ngurah Agung Suaryana. 2013. Pengaruh Profitabilitas dan Investment Opportunity Set Pada Struktur Modal.E-Jurnal Akuntansi Universitas Udayana, IV(2): 299-314.

Wijaya, Anggita Langgeng dan Juli Murwani. 2011. Pengaruh Kepemilikan Manajerial, Leverage dan Profitabilitas Terhadap Kebijakan Investasi Perusahaan. Jurnal Dinamika Akuntansi, III(1).

Yendrawati, Reni dan Febi Rezki Adhianza. 2013. Faktor-Faktor yang Berpengaruh Terhadap Set Kesempatan Investasi (IOS). Jurnal Inovasi dan Kewirausahaan, II (1): 32-41. 